\title{
Gender Stereotypes Portrayed in a Senior High School English Textbook Published by Indonesia Ministry of Education and Culture
}

\author{
Fazl Ahmad Habib, Bambang Arya Wija Putra, Budi Setyono \\ University of Jember \\ E-mail:fazlahmadhabib@gmail.com
}

\begin{abstract}
The study was conducted to elaborate the gender stereotypes in a national senior high school English textbook in Indonesia. The qualitative study is applied and Critical Discourse Analysis is used as the preferable approach. This research provides the development of Mullet's (2018) CDA generic framework analysis which based on Fairclough's (2001) model. The result of the study divulged various gender stereotypes portrayed such as gender firstness, equality, dominance and bias. Many biased stereotypes are found on how the female character being portrayed in leadership matter, social relation, and family. In contrast, in the matter of physical traits, male characters are portrayed to have more and various interests in sports. The gender stereotypes portrayed in both textual and visual contents within the textbook. Many illustrations portrayed women stereotypically biased so do the textual materials such as narrative text, recount text/biography, transactional text, and descriptive text. Somehow, it is suggested that the authors should consider the position and the portrayal of gender stereotypes as problematic as proven by many previous studies.
\end{abstract}

Keywords: Critical Discourse Analysis, Fairclough Model, Gender Stereotypes, Textbook.

\section{Introduction}

Classrooms as the part of schools are microcosms of society, mirroring its strengths and ills alike, following the socialization patterns [1]. For this reason, textbooks are considered the next important factor in the second/foreign language classroom after the teacher. In fact, textbook as the platform to deliver language materials, has been consider as prior tool in the teaching learning process. Therefore, a textbook is much potential to carry the cultural values and personal beliefs in the society.

In Indonesia, textbooks are published by Ministry of Education and Culture. According to Pillay (2018) the textbooks that are endorsed by the state need to present knowledge selections in accordance with the content listed in the prescribed curriculum of the country [2]. On the one hand, Indonesia Government maintains the publication of the textbooks that is based on its regulation, which stated "ideologically, school textbooks in Indonesia are required to avoid pornographic content, extreme ideology, radicalism, violence, ethnic-religious-racial sentiments, and gender bias" [3]. On the other hand, many studies divulge gender issues that are carried by the existence of the textbooks. Setyono (2018) stated that between 2003 and 2018, previous studies on gender issues (e.g., gender biases, gender stereotypes, gender construction, gender roles, gender equality) in language textbooks have been situated in inner, outer, and expanded circle countries (Australia, Hongkong, Japan, Uganda, Pakistan, Ethiopia, USA, and Indonesia) [3]. Therefore, it is a matter of fact that gender issues found in language textbooks, is reasonably discussed.

As quietly appear in textbooks, gender issues (stereotypes, construction, role/discrimination, inequality /dominance) should be seen critically by learners and teachers. In line with Pillay (2013) that the skills of a critical linguist (using critical discourse analysis [CDA]) are essential if individuals (teachers and learners) wish to unearth the subtext of school textbooks [2]. Many studies reveal the gender issues found in the textbook as discourses in the forms of both textual and visual contents. According to Jannati (2015), that conducted study focused on visual image analysis to signify the personal trait about gender role [4]. And the semiotic analysis is used as the approach to complete the qualitative study. The results showed the existence of gender bias and stereotypes based on the total number of adjectives used in textbooks. In a sense, CDA attempts to make visible social phenomena that often pass unnoticed [5]. In conclusion, CDA is eligible to critically elaborate the gender issues in textual and visual contents of textbooks. For this reason, the researcher tends to answer the question, "How are gender stereotypes portrayed in Senior High school English textbook published by the Indonesian Ministry of Education and Culture?

\section{Literature Review}

\section{Stereotypes}

attributes that are often applied to a group of people as a result of accepted beliefs about the members of the group. The accepted beliefs are recognized as two stereotypes components. Those are, descriptive components, or beliefs about how a person (female or male) typically act, and prescriptive components, or beliefs about how he/she should act. Interchangeably, [6] stated that stereotypes also have important predictive power for individuals' beliefs about their own ability. Moreover, Ramiah (2010) emphasized that beliefs about the personal attributes of a group of people, and can be over-generalised, inaccurate, and resistant to change in the presence of new information [7]. In general, Goffman's (1987) elaboration on stereotypes can be a result of circumstances of society which remain individual to have perspective undesirably somehow the social activities are considerably agreed [8]. This reciprocal relation between 
stereotypes and belief determine a person act whether it is considerably agreed or undesirably accepted. In conclusion, stereotypes are about beliefs of groups' typical or suggestible activities that are interchangeably based on female/male's attributes.

\section{Gender Stereotype and Issues}

Gender stereotypes grow out of our historical and cultural understanding of the roles of men and women in society - many, or even most, of which are out moded but continue to be powerful [9]. Aryangga and Brewer Simply put, gender stereotypes are generalizations about the roles of each gender [10]. The roles are often acknowledged as inaccurate generalizations of the male and female attributes. As beliefs of own ability are strongly influenced by gender stereotypes [11].

Furthermore, beliefs are most biased by stereotypes [11]. Gender bias can arise when people judge men and women differently as a result of the use of gender stereotypes [12]. Gender bias shows us how gender stereotypes affect our responses and assumptions even when we consciously disagree with them [9]. "gender bias" refers to the unfair treatment to one gender by under-representation comparing the opposite gender [13]. People hold stereotypes about men's and women's physical traits (muscular, soft, hairy), social roles (provides, does house work), and occupations (engineer, librarian). For this reason, gender bias mislead women to play domestic or traditional social roles (e.g. cooking, knitting and babysitting), to participate in limited social roles (e.g. fashion designers), and to suffer from unequal treatment in doing business and in achieving managerial and political positions [3].

It can be concluded that stereotypes limit women roles. In contrast, men have no boundaries in doing lots of activities. As over-generalized, inaccurate or resistant belief (as previous state) undesirably affects a person measures her/his own attribute or ability. Hence, for this reason, overgeneralized, inaccurate or resistant possibly causes misconception of stereotypes components. The misconception maintains the appearance of bias, dominance, and inequality.

\section{Previous Study on Gender Stereotypes}

Setyono (2018) investigated the portrayal of women in a series of EFL textbooks for Senior High School X, XI, and XII which were published by the MONED (Ministry of Education and Culture) [3]. To obtain the data, he used the visual and textual data comprising a dialogue text, a dialogue text with pictures, a job application, and a reading text with pictures. The findings revealed that the female characters in gendered discourses indicated the continuation of gender stereotypes. However, the positive images of female characters were also portrayed as well like femaleleader role in public. As a result, it encourages students to understand the gender issues, diminish the gender misconceptions, and promote the gender equality through the female and male views.

Tajeddin (2010) evaluated roles of both gender by using a quantitative and qualitative analyses of the images in terms of the active role, gaze direction, visual techniques, body display, and spaces [14]. The result indicated that women are frequently shown as the reactive participants of the image. In contrast, men were portrayed as the active participants of the images holding more social power and prominence. Additionally, Barton and Sakwa (2012) proved that, the gender inequality in the secondary textbook in Uganda was embodied by the differences of occupational roles in which man was getting better paying and high-status jobs such as doctor, judge, and manager while the women's occupational roles were not only limited but also restricted mainly to the domestic sphere [15].

Considering the previous studies, this research further portrayed the gender stereotypes on National EFL Textbook in Indonesia published by Ministry of Education and Culture. As it is mentioned that gender stereotypes covers the gender roles, identity, firstness, equality, bias and dominance, this study provided categorization in occupational area, social relation, personal interests, cultural activities, digital activities, folktales, and news as those can be found in visual materials (images, pictures, photographs, illustrations) and textual materials (reading texts, dialogue texts) of the textbook.

\section{CDA and Framework Analysis}

Critical Discourse Analysis (CDA) holds much promise for educational research. Researchers using CDA can describe, interpret, and explain the relationships among language and important educational issues [16]. For this study, Fairclough's (2001) three-dimensional CDA framework was used as fundamental framework of analysis [17]. This framework covers the linguistics description, interpretation of the reciprocal relation between social reality and social product (text), and the explanation of linguistics description, social/cultural reality and social product. mention text as the content of analysis, on the other hand [17]. Fairclough (1992) stated the important values of images, "Constructing images in the other sense - ways of publicly presenting persons, organizations, and commodities, and the construction identities or personalities for them [18]." Principally, language (and more broadly "semiosis", including for instance signification and communication through visual images) is an element of the social at all levels [19].

Therefore, the researcher selected CDA an appropriate analysis tool for textual and visual images of the textbook. Moreover, the analysis framework was adapted and developed based on the Fairclough's (2001) threedimensional stages of CDA and Mullet (2018) CDA generic framework of analysis.

\section{Method}

The present study aimed to analyze gender stereotypes portrayed in an EFL textbook for senior high school students in Indonesia. The gender stereotypes that was analyzed include visual and textual materials in the textbook. CDA relies on a collection of techniques for the study of language use as a social and cultural practice [17]. CDA focuses on social problems and not on scholarly paradigms [20]; as a result, CDA can be used to understand and solve problems with any theory or method that may be relevant. Procedures, 
techniques, and processes are all selected based on their relevance to the research purpose [21]. Moreover, CDA scholars seek to expose these imbalances by looking behind words to uncover the ideological assumptions in written texts or oral speech [22] in order to provoke people to corrective action [18]. CDA is analysis of the dialectical relationships between discourse (including language but also other forms of semiosis, e.g. body language or visual images) and other elements of social practices [19].

The qualitative design is applied to this research. The interpretation of the data was narrated descriptively to provide clear elaboration of the portrayed gender stereotypes. As previously stated, the analysis was adapted and developed based on the Fairclough's (2001) threedimensional stages of CDA and Mullet (2018) CDA generic framework of analysis [17].

\section{Data Collection Method}

Data of the present study were gender stereotypes in an EFL textbook for Grade X of senior high school published by the Ministry of Education and Culture which portrayed in textual and visual materials/contents. The English textbook for grade X was selected because: (1) it was written based on English Curriculum 2013, (2) it contained gender stereotypes both in textual and visual materials, (3) it was written by Indonesian authors who understood the Indonesian ELT context, and (4) it was used in many senior high schools in Indonesia.

This textbook is entitled "Bahasa Inggris" published by Pusat Kurikulum dan Perbukuan, Balitbang, Kemendikbud in 2017. It is from Utami Widiati, Zuliati Rohmah, dan Furaidah as the writers. It consists of 15 chapters in 220 pages. Becoming a part of the 2013 Curriculum, this textbook highlights the importance of balancing student attitudes, knowledge and skills.

By selecting the materials that contain gender stereotypes, the documentation was applied to provide samples or whole materials. The textual materials/contents were gathered from passages; letters, complimenting/dialogues, descriptive texts, recount texts, biographical text, narrative texts). The visual materials/contents were obtained from each chapter of the textbooks which provided images, photograph and illustration/cartoon. There were 12 textual contents and 12 visual contents selected for analysis which contained gender stereotypes.

\section{Data Analysis Method}

The researcher provided a table of categorization in occupational area, social relation, cultural activities, digital activities, folktales, and news as those can be found in visual materials (images, pictures, photographs, illustrations) and textual materials (reading texts, dialogue texts) of the textbook. By highlighting or spotting textual and visual materials which contained gender stereotypes; gender roles, identity, firstness, equality, bias and dominance. This table of categorization was provided after the analysis and the interpretation was done.

As the researcher also needs to have the interpretation of both textual and visual materials, the analysis was adapted and developed based on the Fairclough's (2001) threedimensional stages of CDA and Mullet (2018) CDA generic framework of analysis. As it is mentioned that, Fairclough's (2001) CDA model was to elaborate textual contents, Mullet (2018) generic framework of analysis is considered to provide specific interpretation of the data [17]. Mullet (2018) developed 7 stages of analysis from 3 stages analysis of Fairclough's (2001) model; Select the discourse, locate and prepare data sources, explore the background of each text, code texts and identify overarching themes, analyze the external relations in texts (interdiscursivity), analyze the internal relations in the texts, and interpret the data. These stages are only developed to analyze textual contents. Therefore, the researcher adapted those Fairclough's (2001) framework and Mullet's (2018) framework into a flowchart of analysis. Procedures of Analysis [23].

To analyze the textual and visual materials/content that contained the gender stereotypes in English textbook, some steps are developed as the following flowchart,

identification $\Rightarrow$ code $\Rightarrow$ analysis $\Rightarrow$ interpretation discussion

Figure 1. Procedures How to Analyze images and Texts The first step was to identify the textual and visual materials that contain gender stereotypes throughout the chapters in the textbook (decide whether the materials contain gender stereotypes or not). The second was to code the identified textual and visual materials (highlighting or spotting the materials as samples or complete materials). Third, the textual and visual materials were analyzed to show what gender representation implicitly and/or explicitly stated in the pictures (The materials are divided based on gender stereotypes variation and the themes/categorization). The fourth step was to interpret the results of the analysis to reveal the hidden meanings in textual and visual materials (Interpret the reciprocal relations on how society affects the production of materials, and how the materials affect students/society). The final step was to discuss the results of analysis by comparing and contrasting them to the related

theories and findings of previous studies.

\section{Gender Stereotypes in Textual Materials}

Some samples are taken from the textbooks which include the indicated gender stereotypes. The highlighted lines, statements are provided for analysis. In a text entitled 'The Wright Brothers', the stereotype was found. This text is provided to simulate the situation where wright brothers are being interview in TV station. The text was in written dialogues. Some samples are taken here. In fact, the text did not mention the existence of a woman even the woman role.

1. Our dad gave us a toy helicopter that flow with the help of rubber bands.

2. We've been interested in the idea since then.

3. Our father has asked us not to fly together. He said it's for the safety reason.

4. Yes, we will continue making more experiment so that airplane will be available for everyone soon.

Research conducted in women's studies by FujimuraFanselow [24] found that unequal power sharing between the sexes had a negative effect on female students participating in class. This is likely because when one sex is excluded 
from dialogues, their opportunities to practice the language will also be reduced. This phenomenon places the other sex in a more dominant position, giving them the opportunity to improve their language skills more rapidly. This indirectly leads readers to have biased stereotypes of women which related to occupational area.

The next text is a recount text that based on events written chronologically. The theme of the text is related to survival, history, collonialism, and leadership. As stated "Cut Nyak Dhien was a leader of the Acehnese guerrilla forces during the Aceh War." to spot the leadership of Cut Nyak Dhien. She is one of the Indonesian female heroes. In case, Indonesian people recognize her, but not in detail. This text provides her story of struggle during the dutch collonialism;

1. Her husband Ibrahim Lamnga fought to reclaim VI mukim

2. The Dutch army welcomed him and appointed him as a commander, giving him the title of Teuku Umar Johan Pahlawan.

3. Teuku Umar secretly planned to betray the Dutch

\begin{tabular}{|c|c|c|}
\hline $\begin{array}{l}\text { Material/ } \\
\text { Contents }\end{array}$ & $\begin{array}{c}\text { Gender Stereotypes } \\
\text { Variation }\end{array}$ & Themes \\
\hline $\begin{array}{l}\text { Alif } \\
\text { Achievement }\end{array}$ & $\begin{array}{l}\text { Gender Bias, Role, } \\
\text { Dominance, and } \\
\text { Equality }\end{array}$ & $\begin{array}{l}\text { Occupational area, Social } \\
\text { Relation }\end{array}$ \\
\hline $\begin{array}{l}\text { Citta Won } \\
\text { Competition }\end{array}$ & Gender Equality & Social Relation, Friendship \\
\hline $\begin{array}{l}\text { Tanjung } \\
\text { Putting } \\
\text { National Park }\end{array}$ & Gender Firstness & $\begin{array}{l}\text { News, Cultural } \\
\text { Activities/Picnic }\end{array}$ \\
\hline $\begin{array}{l}\text { Let's Visit } \\
\text { Niagara Falls }\end{array}$ & Gender Firstness & $\begin{array}{l}\text { News, Cultural } \\
\text { Activities/Picnic }\end{array}$ \\
\hline $\begin{array}{l}\text { Interview } \\
\text { with Wright } \\
\text { Brothers }\end{array}$ & $\begin{array}{l}\text { Gender Dominance } \\
\text { and Firstness }\end{array}$ & $\begin{array}{l}\text { News/Information, Family, } \\
\text { Occupational Area, Social } \\
\text { Relation }\end{array}$ \\
\hline B. J. Habibie & $\begin{array}{l}\text { Gender Role, } \\
\text { Firstness and } \\
\text { Dominance }\end{array}$ & $\begin{array}{l}\text { News/Information, Family, } \\
\text { Occupational Area, Social } \\
\text { Relation }\end{array}$ \\
\hline & $\begin{array}{l}\text { Gender Role, } \\
\text { Firstness and } \\
\text { Dominance }\end{array}$ & $\begin{array}{l}\text { News/Information, Family, } \\
\text { Occupational Area, Social } \\
\text { Relation }\end{array}$ \\
\hline & Gender Role, & $\begin{array}{l}\text { Folktale, Family, Social } \\
\text { Relation }\end{array}$ \\
\hline $\begin{array}{l}\text { Malin } \\
\text { Kundan }\end{array}$ & $\begin{array}{l}\text { Gender Role, } \\
\text { Firstness and } \\
\text { Dominance }\end{array}$ & $\begin{array}{l}\text { Folktale, Family, Social } \\
\text { Relation }\end{array}$ \\
\hline & $\begin{array}{l}\text { Gender Role, } \\
\text { Firstness and } \\
\text { Dominance }\end{array}$ & $\begin{array}{l}\text { Folktale, Family, Social } \\
\text { Relation }\end{array}$ \\
\hline
\end{tabular}

He instead deserted with his troops taking with them heavy equipment, weapons, and ammunition, using these supplies to help the Acehnese.

5. Cut Nyak Dhien was a leader of the Acehnese guerrilla forces during the Aceh War.

6. She was educated in religion and household matters.

7. and many men proposed to marry her.

8. Cut Nyak Dhien was enraged and swore to destroy the Dutch

9. but in the end she was exiled to Sumedang, West Java because the Dutch were afraid she would mobilize the resistance of Aceh people.

Cut Nyak Dhien is described as a powerful woman which she could lead (6) Aceh guerilla during Aceh War. She also had educational experience, but the writer did not mention her institution. According to Setyono's (2018) statement that culturally the Indonesian girls and woman (regardless of their social status) are obliged to accept their dual functions both as a wife (who is in charge of household activities) and a career woman (who is also responsible for earning money) for their family. The conventional culture made her being educated for matter of households as domestic role. Thus, the text portrays both negative and positive gender stereotypes. In fact, the positive portrays are most found in the text. It is a complete perspective and description of personality of Cut Nyak Dhien as an influencing woman. As a result, the table of categorization form textual materials was portrayed as followed :

Table 1. Categorization Form Textual Materials

\begin{tabular}{|l|l|l|}
\hline \multicolumn{1}{|c|}{$\begin{array}{c}\text { Material/ } \\
\text { Contents }\end{array}$} & $\begin{array}{l}\text { Gender Stereotypes } \\
\text { Variation }\end{array}$ & \multicolumn{1}{c|}{ Themes } \\
\hline $\begin{array}{l}\text { Letter form } \\
\text { Hannah }\end{array}$ & $\begin{array}{l}\text { Gender Bias and } \\
\text { Role }\end{array}$ & $\begin{array}{l}\text { Social Relation, } \\
\text { Friendship, } \\
\text { Technology/Digital } \\
\text { Activities, Family }\end{array}$ \\
\hline $\begin{array}{l}\text { Letter from } \\
\text { Saidah }\end{array}$ & $\begin{array}{l}\text { Gender Bias and } \\
\text { Role }\end{array}$ & $\begin{array}{l}\text { Social Relation, } \\
\text { Friendship, } \\
\text { Technology/Digital } \\
\text { Activities, Family }\end{array}$ \\
\hline
\end{tabular}

The woman at the right side whispering to three other women. Those three women are listening to the woman at the right side. This spots that by the time women are in group they are having topic to talk about. In other word they are typically talkative. Instead of the image is showing four women are whispering, it implies that women are talkative. These illustrated the social practices, such as complimenting physical appearance/beauty and gossiping unnecessary things are categorized as the stereotyped/negative portrayals of women [3]. As an example of unfair stereotypes, this will lead male students to have opportunities to judge female students as talkative and more.

Your teacher will ask you to make groups of 4 students and show you how to play Chinese Whisper. Listen to your teacher's explanation and do the activity as quickly as possible. Try to be the winner.
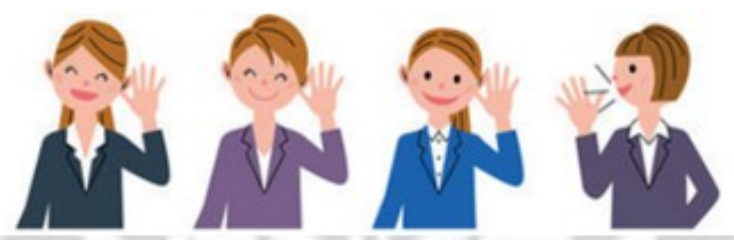

Picture 1. Four Women doing Chinese Whisper 


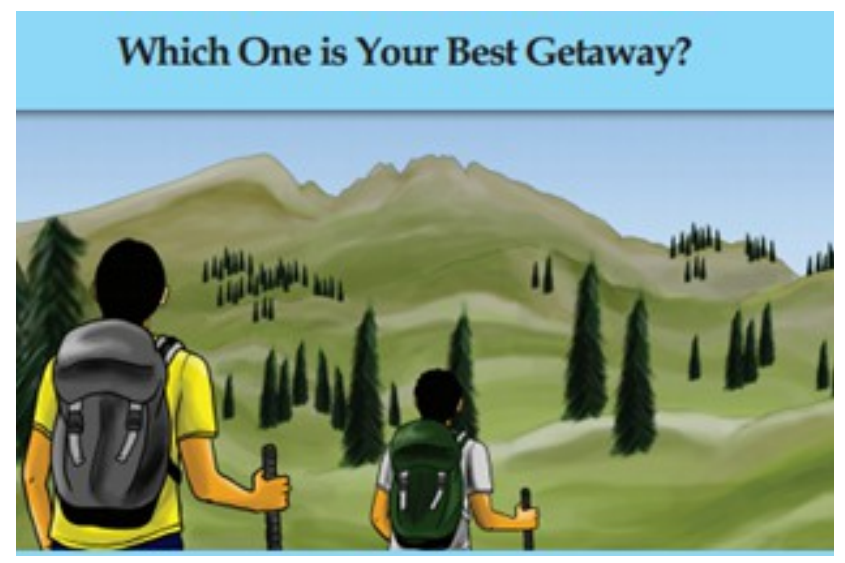

Picture 2. People Climb Mountains

Based on the picture above, it is clear that the stereotype of a climber is more appropriate for men than for women. As a result, the reader will assume that climbing activities because the physical advancement is more suitable for men and not natural for women. people hold stereotypes about men's and women's physical traits (muscular, soft, hairy) [25]. For this reason, a various sport interests are optional only for men. This portrayal, is a clear information and implicitly lead learners to close to misconception of gender.

The Picture 3 describes a famous soccer ball namely Lionel Messi. In a sense, a soccer ball is more inclined by men than women. In reality, although a soccer ball from women team is existing in almost every country, some people still argue the soccer ball is more suitable for man. Therefore, selecting the image that is not appropriate in describing gender justice will have bad implications on the condition of the reader, namely children. As Tajeddin (2010) explained that gender is a part of our identity which consciously and unconsciously affects our self-image and interpersonal attitudes [14]. Thus, when a student analyzes the picture and assumes that the work has been divided based on the character of sexes, the gender biases and stereotypes will easily occur. For instance, if footballers are always presented as males in textbooks, this may negatively affect female children, and restrict their wishes to play soccer by believing that this occupation is more acceptable for males. Therefore, writers should consider excluding stereotypes from textbooks because the presence of stereotypical views can cause problems throughout children's development [26].

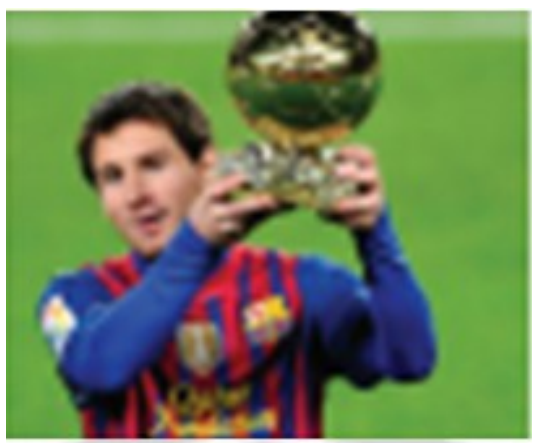

Picture 3. A Famous Soccer Ball

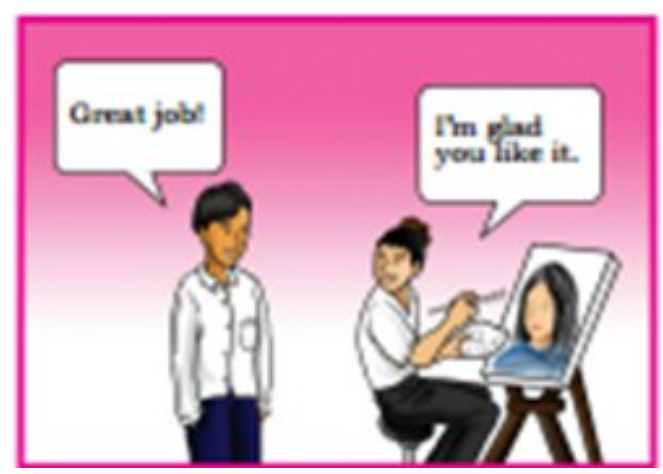

Picture 4. Painting Activities

The picture above depicts a man on the left position commending the other man on the right as a great painter. On the other hand, there is a woman who becomes an object in the painting. The men in the picture are likened to being more active and creative, whereas women only function as male objects. In reality, women are treated unfairly as the objects of sex exploitations [3]. This illustration thus portrayed the gender bias by stereotyping female character to appear passively. This of course indirectly emphasized the belief that male is more creative and active than female. Moreover, it possibly misleads female and male learners to accept the bias. As a result, a table of visual materials categorization based on gender stereotypes found is portrayed as followed : ?

Table 2. Visual Materials Categorization

\begin{tabular}{|c|c|c|}
\hline $\begin{array}{c}\text { Materials/ } \\
\text { Contents }\end{array}$ & $\begin{array}{c}\text { Gender Stereotypes } \\
\text { Variation }\end{array}$ & Themes \\
\hline aracter & $\begin{array}{l}\text { Gender Bias, } \\
\text { Dominance, } \\
\text { Firstness }\end{array}$ & $\begin{array}{l}\text { Occupational Area, } \\
\text { Social Relation }\end{array}$ \\
\hline $\begin{array}{l}\text { Four Male } \\
\text { Characters (Image 2) }\end{array}$ & $\begin{array}{l}\text { Gender Bias, } \\
\text { Dominance, } \\
\text { Firstness }\end{array}$ & $\begin{array}{l}\text { Family, Interests, } \\
\text { Social Relation }\end{array}$ \\
\hline $\begin{array}{l}\text { Female Compliments } \\
\text { Male Character } \\
\text { Plays Guitar (Image } \\
\text { 3) }\end{array}$ & $\begin{array}{l}\text { Gender Bias, Role, } \\
\text { Dominance }\end{array}$ & $\begin{array}{l}\text { Social Relation, } \\
\text { Interest }\end{array}$ \\
\hline $\begin{array}{l}\text { Two Females } \\
\text { Complimenting Each } \\
\text { Other (Image 4) }\end{array}$ & $\begin{array}{l}\text { Gender Equality, } \\
\text { Bias }\end{array}$ & $\begin{array}{l}\text { Social Relation, } \\
\text { Friendship }\end{array}$ \\
\hline $\begin{array}{l}\text { Two Male } \\
\text { Characters } \\
\text { Complimenting Each } \\
\text { Other (Image 5) }\end{array}$ & $\begin{array}{l}\text { Gender Firstness, } \\
\text { Bias, Dominance }\end{array}$ & $\begin{array}{l}\text { Social Relation, } \\
\text { Interests, } \\
\text { Friendship }\end{array}$ \\
\hline $\begin{array}{l}\text { A Group of Boys } \\
\text { and Girls (Image 6) }\end{array}$ & $\begin{array}{l}\text { Gender Dominance, } \\
\text { Equality, Bias }\end{array}$ & $\begin{array}{l}\text { Social Relation, } \\
\text { Friendship, Interest }\end{array}$ \\
\hline $\begin{array}{l}\text { A Boy Daydreaming } \\
\text { (Image 7) }\end{array}$ & $\begin{array}{l}\text { Gender Dominance } \\
\text { and Bias }\end{array}$ & Interest \\
\hline $\begin{array}{l}\text { A Normal Female } \\
\text { Character and A tiny } \\
\text { Male character } \\
\text { (Image } 8 \text { ) }\end{array}$ & $\begin{array}{l}\text { Gender Role, } \\
\text { Firstness and } \\
\text { Dominance }\end{array}$ & Social Relation \\
\hline $\begin{array}{l}\text { A Normal Female } \\
\text { Character Interacts } \\
\text { with A tiny Male }\end{array}$ & $\begin{array}{l}\text { Gender Role, } \\
\text { Firstness and } \\
\text { Dominance }\end{array}$ & $\begin{array}{l}\text { Social Relation, } \\
\text { Interest }\end{array}$ \\
\hline
\end{tabular}




\begin{tabular}{|l|l|l|}
\hline character (Image 9) & & \\
\hline $\begin{array}{l}\text { Two Male } \\
\text { Characters Climbing } \\
\text { (Image 10) }\end{array}$ & $\begin{array}{l}\text { Gender Role and } \\
\text { Dominance }\end{array}$ & $\begin{array}{l}\text { Social Relation, } \\
\text { Interest }\end{array}$ \\
\hline $\begin{array}{l}\text { A soccer star Raises } \\
\text { a Trophy }\end{array}$ & $\begin{array}{l}\text { Gender Role, Gender } \\
\text { Firstness, Gender } \\
\text { Dominance }\end{array}$ & Interest \\
\hline $\begin{array}{l}\text { Two } \\
\text { Historical/Populer } \\
\text { Engineer }\end{array}$ & $\begin{array}{l}\text { Gender Role, } \\
\text { Dominance }\end{array}$ & $\begin{array}{l}\text { Occupational Area, } \\
\text { Interest, Family }\end{array}$ \\
\hline
\end{tabular}

\section{Conclusion and Suggestion}

This study was conducted to portray gender stereotype in English Textbook for senior high school entitled 'Bahasa Inggris', a national and published by Ministry of Culture and Education of Indonesia. As the focus of the study to provide the portrayal of gender stereotypes in the textual and visual contents, in which the gender stereotypes are elaborated and varied into gender bias, role, dominance, equality, and firstness. Overarching themes also considered as to ease the categorization. For examples, occupational area, social relation, family, interest, friendship and digital activities. $\mathrm{CDA}$ is used as the tool of analysis. Hence, the researcher developed the framework and steps of analysis from Fairclough's (2001) model and Mullet's (2018) model. The results portrayed the gender stereotypes both fairly and unfairly which varied from gender bias, dominance, role, firstness, and equality. For examples, the researcher found 'Cut Nyak Dhien' as a national was portrayed fairly in textual material. The writer mentioned her 'leadership' strongly that indirectly inform or implicitly show female is able to close with dominance. Besides, the researcher also portrayed unfair stereotypes about physical trait in visual materials. Some illustrations show that men's sport interests are varied, such as sport, climb and fishing which mislead to gender bias. Finally, the textual and visual materials from the textbook, for sure, contain gender stereotypes variously.

As an empirical contribution to further researches in educational area, there are some suggestion provided. Regards the textbooks are nationally used for senior high school students, the contents/materials which contain gender stereotypes should be considerably fostered. Both fair and unfair portrayal of gender stereotypes are matter to students and teachers for the conduction the teaching learning process. Besides, teachers are also required to more critical to provide the materials from the textbooks to students in which to avoid the misconception of the gender. At the final, further research are open to have similar focus of the research with different approach for wider and deeper elaboration of gender stereotypes.

\section{References}

[1] Gorgadze, N. (2017). Textbook Analysis of the Primary Education in Georgia from Gender Perspective. International Journal of Multilingual Education, 1-10.

[2] Pillay, P. (2018). The 'firstness' of male as automatic ordering: Gendered discourse in Southern African Business Studies school textbooks. The Journal for Transdisciplinary Research in Southern Africa, 1-9.

[3] Setyono, B. (2018). The Portrayal of Women in Nationally Endorsed English as a Foreign Language

[4] Jannati, S. (2015). Gender Representation in EFL Textbook: A Case of ILI Pre-Intermediate Series. Journal of Applied Linguistics and Language Research, 211-222.

[5] Vaara, E. (2016). Critical discourse analysis as methodology in Strategy as Practice research

[6] Coffmann, K., (2019), Stereotypes and Belief Updating

[7] Ramiah, A. A. (2010). The Social Psychology of Discrimination: Theory, Measurement and Consequences. In Making Equality Count (pp. 84-112). Dublin.

[8] Goffman, E. (1987). Gender Advertisement. New York: HARPER TORCHBOOKS.

[9] Godsil, R. D. (2016). The Effect of Gender Roles, Implicit Bias, and Stereotype Threat on The Live of Women and Girls. The Science of Equality.

[10] Bakhta Abdelhay, W. B. (2015). Gender Stereotyping through Textbook Illustrations: A Case Study of Algerian Middle School Textbook- Spotlight on English 1. Mediterranean Journal of Social Sciences, $435-440$

[11] Katherine Coffman, M. C. (2019). Stereotypes and Belief Updating.

[12] Koch A.J., D'Mello S.D., Sacket P.R., A meta-analysis of gender stereotypes and bias in experimental simulations of employment decision making. The Journal of Applied Psychology. 100: 128-61

[13] Maryam Beiki, N. G. (2017). The Analysis of Iranian English Textbook: A CDA Study Based on Norman Fairclough's 2001 Model. International Journal of Humanities and Cultural Studies, 55-67.

[14] Zia Tajeddin, M. J. (2010). Gender representation and stereotyping in ELT textbooks: A critical image analysis. TELL, 51-79.

[15] Barton, A. and Sakwa, L.N. (2012). The Representation of Gender in English Textbooks in Uganda. Pedagogy, Culture and Society, 20 (2), 173-190.

16] Rogers, P.J. et al, (2016). Does low-energy sweetener consumption affect energy intake and body weight? A systematic review, including meta-analyses, of the evidence from human and animal studies, Int. J. Obes 40:381-394

17] Fairclough, Norman (2001). Language and Power (2nd edition). London: Longman

18] Fairclough, Norman (1992). Discourse and Text: Linguistic Intertextual Analysis within Discourse Analysis. Discourse and Society 3(2): $193-217$

[19] Fairclough, Norman, Graham, Phil, Lemke, Jay \& Wodak, Ruth (2004). Introduction. Critical Discourse Studies 1(1): 1-7.

[20] Van Dijk, T. A. (2007). Critical Discourse Analysis. 352-371.

[21] Van Dijk, T. A. (1993). Principles of Critical Discourse Analysis. Discourse and Society, 4, 249-283.

[22] Fairclough, Norman (1989). Language and Power. London: Longman.

[23] Mullet, D. R. (2018). A General Critical Discourse Analysis Framework for Educational Research. Journal of Advance Academic, $1-27$.

[24] Norton, B., \& Pavlenko, A. (Eds.). (2004). Gender and English language learners. Alexandria, VA: TESOL.

[25] Lippa, R. A. (2005). Gender, nature, and nurture (2nd ed.).

[26] Arta Toci, M. A. (2013). Gender Stereotypes in Current Children's English Books Used in Elementary Schools in the Republic of Macedonia. American International Journal of Contemporary Research, 32-38.Lawrence Erlbaum Associates Publishers. 